\title{
Peripherally inserted central catheter in newborns: association of number of punctures, vein, and tip positioning
}

\author{
Cateter central periférico em recém-nascidos: associação entre o número de punções, \\ veia e posicionamento da ponta \\ Catéter central de inserción periférica en recién nacidos: asociación entre número de \\ punciones, vena y posicionamiento de la punta
}

How to cite this article:

Carneiro TA, Nobre KSS, Fontenele FC, Façanha APM, Ferreira RP. Peripherally inserted central catheter in newborns: association of number of punctures, vein, and tip positioning. Rev Esc Enferm USP. 2021;55:e20210043. https://doi.org/10.1590/1980-220X-REEUSP-2021-0043

Thaís Aquino Carneiro ${ }^{1}$

Keline Soraya Santana Nobre ${ }^{1}$

Fernanda Cavalcante Fontenele ${ }^{1}$

Ana Paula Melo Façanha ${ }^{1}$

Roberta Pinheiro Ferreira ${ }^{1}$

${ }^{1}$ Universidade Federal do Ceará, Fortaleza, CE, Brazil.
Corresponding author:

Thaís Aquino Carneiro

Rua Azevedo Bolão, 1388

60455-165 - Parquelândia, Fortaleza, CE, Brazil

thais.aquinoc@gmail.com

\begin{abstract}
Objective: to assess the use of peripherally inserted central catheters regarding the neonate's profile, indications for use, and catheterized vein; the relation between the number of puncture attempts and vein; and assessment of the catheter tip position. Method: documentary, descriptive, retrospective, quantitative study, developed in a tertiary maternity hospital in Ceará. A total of 3,005 PICC insertion formularies was included and 1,583 were excluded due to incomplete data, with a convenience sampling of 1,422 insertions being obtained. Results: There were 1,200 (84.4\%) newborns with gestational age below 37 weeks; 781 (54.9\%) males; Apgar score above 7 in the first (628-44.2\%) and fifth minutes (1,085-76.3\%); and weight between 1,000 and 1,499 grams on the day of insertion (417-29.3\%). Antibiotic therapy had 1,155-53.8\% indications for insertion; the basilic was the most used vein (485-34.1\%); basilic and cephalic veins had lower median puncture attempts and 1,124-79\% insertions were centrally positioned. Conclusion: The results of this research highlight the continuous need to improve technical-scientific knowledge to qualify actions in neonatology.
\end{abstract}

\section{DESCRIPTORS}

Catheterization, Peripheral; Catheterization, Central Venous; Infant, Newborn; Nursing Care; Intensive Care Units, Neonatal. 


\section{INTRODUCTION}

Newborns admitted to a neonatal unit require individualized care, according to the complexity of the clinical picture. The care team works aiming to restore health, quality of life, healthy growth and development of these newborns, who are mostly premature, undergoing invasive procedures, requiring knowledge and constant improvement from professionals ${ }^{(1)}$.

The use of intravenous therapy is critical in the health recovery of newborns admitted to a neonatal unit. "Venipuncture consists of inserting a device inside the vessel, guided by indications and techniques, as well as the selection and use of appropriate material for this invasive procedure. Long-term stay in the intensive care and in the intermediate care units, associated with therapeutic demands and fragility of the venous network, especially in low birthweight newborns, predisposes them to multiple peripheral punctures, stress, pain, and increased risk of infection" (2).

Theoretical, scientific and technical knowledge are essential to obtain a venous access that guarantees safe infusion of irritating and vesicant solutions, with the Peripherally Inserted Central Catheter (PICC) being indicated for newborns undergoing intravenous therapy for a prolonged time ${ }^{(3)}$.

The PICC has advantages, such as the reduction of multiple puncture attempts and pain, the reduction of discomfort and stress; the possibility of insertion at the bedside; safe route for antibiotic administration; Extended Parenteral Nutrition (NPP); excellent route for chemotherapy; longer permanence time and lower risk of contamination compared to other devices; and preservation of the peripheral venous network ${ }^{(4)}$. Thus, it is relevant to assess the approaches used in PICC insertion in neonatology, for better decision-making.

The insertion of PICC is related to low incidence of complications, reduction of infections; it is safe and effective, being considered the device of choice for central vascular access in newborns ${ }^{(4)}$. This procedure can be performed by nurses, according to COFEN's Resolution No. 258/2001, provided that they are qualified and trained. The first article of this resolution says that the nurse is allowed to insert a central peripheral catheter and the second article says that the nurse shall take qualification and/or professional training to perform such activity ${ }^{(5)}$.

The nursing team shall implement evidenced good practices, through the verification of insertion in a vein that allows insertion in the first puncture, removal at the end of treatment, and positioning in the caval-atrial junction ${ }^{(6)}$. The catheter shall be positioned with the use of anatomical measurement, performed before the beginning of procedure; to confirm the central position of the device, a chest $\mathrm{x}$-ray is required after insertion. Tip positioned outside the central vascular system is associated with a significant increase in the risk of device malfunction, fibrin formation and venous thrombosis, infiltration, extravasation, and tissue injury ${ }^{(6,7)}$.

In this context, the nursing professional needs knowledge about which vein is most associated with the lowest number of punctures necessary for its insertion, as well as about the central positioning of the tip. This way, nurses will be able to better plan their actions to improve PICC insertion, choosing the most appropriate vein. Good practices favor patients' safety, as these patients are in a period of great vulnerability.

Therefore, this study aimed at assessing the use of peripherally inserted central catheters in relation to the neonate's profile, the indications for use, and the vein catheterized; the relation between the number of puncture attempts and vein; and the catheter tip position.

\section{METHOD}

\section{Design of Study}

This is a documentary, descriptive, retrospective study with a quantitative approach.

\section{LOCAL}

The study was carried out in a Conventional Neonatal Intermediate Care Unit (CNICU) and in a Neonatal Intensive Care Unit (NICU) of a tertiary maternity hospital that is a reference in the state of Ceará and provides teaching, research, and health care, with open door to care for pregnant women and high- and low-risk newborns, women with gynecological and breast disorders, abortions, and victims of sexual violence. The institution offers outpatient care, emergency care, admission to an adult and neonatal ward, and intensive care unit, kangaroo care, rooming-in, CNICU and NICU, attending 73,154 patient-days in 2018, of which 22,218 in CNICU and NICU ${ }^{(8)}$.

\section{Population, Selection Criteria and Sample}

Data collection took place between November 2018 and July 2019. The institution has routinely filled out this form for all PICC insertions in newborns, since 2012. This was a convenience sampling, with inclusion criteria being all PICC insertion forms completed between 2012 and 2018, totaling 3,005 forms. We excluded 1,583 forms that did not have information about the catheterized vein, the number of puncture attempts, and the location of the catheter tip, so the final sample consisted of 1,422 forms of PICC insertions.

\section{Data Collection}

Data were collected from two consultation sources: the institution's existing database, with information on PICC insertions between 2012 and 2014; and forms for monitoring newborns with PICCs, completed between 2015 and 2018, by the nurses of the intravenous therapy committee of the institution where the study was conducted.

The formulary for monitoring newborns with PICC was developed by nurses responsible for catheter insertion and contains the following categorical variables: admission unit, sex, newborn diagnosis at birth, indication for PICC insertion, catheterized vein, position of the catheter tip, maneuver for PICC advancement, reason for removal; and quantitative variables: gestational age, birthweight and weight on the day of PICC insertion, Apgar score, number of punctures performed, arm circumference, and length of stay. 
The following form variables were analyzed: sex, gestational age, weight on the day of PICC insertion, Apgar score, newborn diagnosis at birth, indication of PICC insertion, number of punctures performed, catheterized vein, catheter tip position.

\section{Data Analysis and Treatment}

Data were entered into the Excel program on Windows 7.0, with data arrangement in tables and characterization of variables through descriptive statistics, with simple frequency distribution. To reduce inconsistencies and data duplication, Excel tools, such as filtering and data validation, were used. In addition, boxplot was used to better distribute the comparison between the data used. The boxplot was used to compare stratified data and differences in the distribution of catheterized veins and number of punctures.

\section{ETHICAl AspeCts}

Ethical aspects were respected, based on standards and guidelines for human research as per Resolution 466/2012 of the National Health Council (CNS). The project was submitted to the Research Ethics Committee of the institution studied and approved under opinion number 3.039.780/2018.

\section{RESULTS}

Table 1 shows the variables related to the profile of newborns undergoing PICC insertion, indications, and catheterized vein. As seen in Table 1, the newborns were premature $(n=1,200 ; 84.4 \%)$, male $(n=781 ; 54.9 \%)$, with an Apgar score above 7 in the first $(n=628 ; 44.2 \%)$ and fifth minute $(n=1,085 ; 76.3 \%)$ and very low weight on the day of PICC insertion ( $\mathrm{n}=417 ; 29.3 \%)$. As for the most prevalent indication, antibiotic therapy $(\mathrm{n}=1,155 ; 53.8 \%)$ is highlighted, followed by parenteral nutrition ( $\mathrm{n}=701 ; 32.6 \%)$, as the most used during PICC use. It is evident that the most catheterized veins by PICC were the basilic $(n=485$; $34.1 \%$ ), followed by the cephalic ( $n=318 ; 22.4 \%)$, and axillary $(\mathrm{n}=280 ; 19.7 \%)$.

Table 1 - Distribution of the number of peripherally inserted central catheters according to gestational age, sex, Apgar score, weight on the day of PICC insertion, indications, and catheterized vein for insertion - Fortaleza, CE, Brazil, 2019.

\begin{tabular}{ccc}
\hline Variables & $\mathbf{N}$ & $\%$ \\
\hline Gestational age $(\mathbf{n}=\mathbf{1 , 4 2 2})$ & 1,200 & 84.4 \\
Preterm $(<37 \mathrm{~s})$ & 184 & 12.9 \\
At term $(\geq 37 \mathrm{~s}<42 \mathrm{~s})$ & 1 & 0.1 \\
Post-term $(\geq 42 \mathrm{~s})$ & 37 & 2.6 \\
No information & & \\
Sex $(\mathbf{n}=\mathbf{1 , 4 2 2})$ & 781 & 54.9 \\
Male & 619 & 43.5 \\
Female & 1 & 0.1 \\
Undetermined & 21 & 1.5 \\
\hline No information & continue...
\end{tabular}

...continuation

\begin{tabular}{ccc}
\hline Variables & $\mathrm{N}$ & $\%$ \\
\hline Apgar 1st minute $(\mathbf{n}=\mathbf{1 , 4 2 2})$ & & \\
$0-3$ & 196 & 13.8 \\
$4-6$ & 386 & 27.1 \\
$7-10$ & 628 & 44.2 \\
No information & 212 & 14.9 \\
\hline Apgar 5th minute ( $\mathbf{n}=\mathbf{1 , 4 2 2})$ & & \\
$0-3$ & 17 & 1.2 \\
$4-6$ & 109 & 7.7 \\
$7-10$ & 1,085 & 76.3 \\
No information & 211 & 14.8
\end{tabular}

\begin{tabular}{|c|c|c|}
\hline $\begin{array}{l}\text { Weight (in grams) on the day of PICC } \\
\text { insertion }(n=1,422)\end{array}$ & & \\
\hline Extremely low weight $(<1,000)$ & 236 & 16.6 \\
\hline Very low weight $(1.000-1,499)$ & 417 & 29.3 \\
\hline Low weight $(1.500-2,499)$ & 395 & 27.8 \\
\hline Normal weight $(2,500-3,999)$ & 200 & 14.1 \\
\hline Macrosomic $(\geq 4,000)$ & 10 & 0.7 \\
\hline No information & 164 & 11.5 \\
\hline \multicolumn{3}{|l|}{ Indications $\left(n=2,148^{*}\right)$} \\
\hline Antibiotic therapy & 1,155 & 53.8 \\
\hline Parenteral nutrition & 701 & 32.6 \\
\hline Venous hydration & 225 & 10.5 \\
\hline Vasoactive drugs & 45 & 2.1 \\
\hline Analgesic measurements & 18 & 0.8 \\
\hline Others & 4 & 0.2 \\
\hline \multicolumn{3}{|l|}{ Catheterized vein $(n=1,422)$} \\
\hline Basilic & 485 & 34.1 \\
\hline Cephalic & 318 & 22.4 \\
\hline Axillary & 280 & 19,7 \\
\hline External jugular & 132 & 9.3 \\
\hline Temporal & 73 & 5.1 \\
\hline Back of the hand & 41 & 2.9 \\
\hline Retroauricular & 34 & 2.4 \\
\hline Saphenous & 27 & 1.9 \\
\hline Antecubital & 23 & 1.6 \\
\hline Popliteal & 4 & 0.3 \\
\hline Tibial & 4 & 0.3 \\
\hline Femoral & 1 & 0.1 \\
\hline
\end{tabular}

*The total number of indications differs from the total number of insertions, as in some insertions the newborns had more than one indication.

Figure 1 demonstrates the relationship between the veins catheterized during PICC insertion and the number of puncture attempts.

The analysis shows that the basilic and cephalic veins have a lower median of puncture attempts than the other catheterized veins.

Figure 2 shows the relationship between the catheterized vein and PICC final position. 


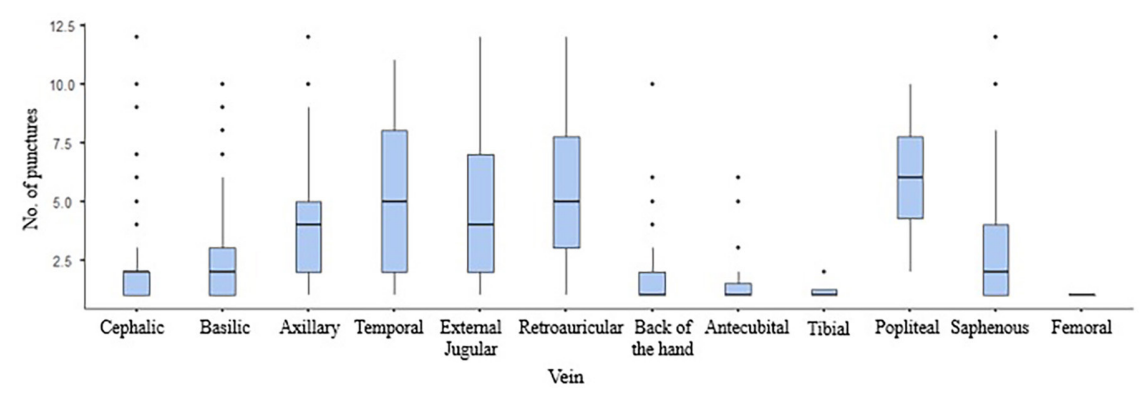

Figure 1 - Boxplot of the number of puncture attempts associated with veins catheterized in PICC insertion - Fortaleza, CE, Brazil, 2019.

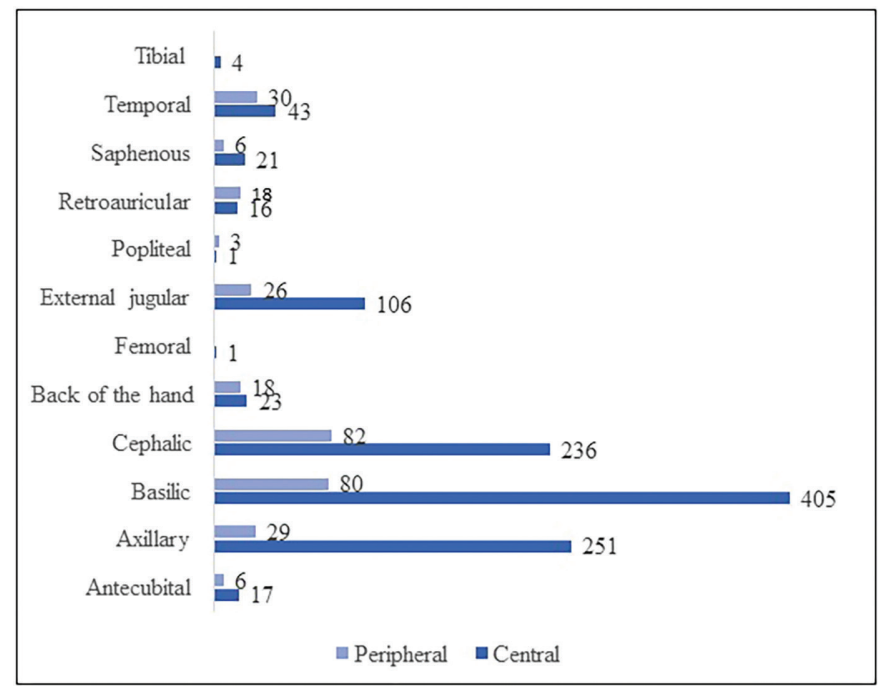

Figure 2 - Catheterized veins versus final positioning of the peripherally inserted central catheter tip - Fortaleza, CE, Brazil, 2019.

\section{DISCUSSION}

The characteristics identified in the results of this study demonstrate the profile of newborns undergoing PICC insertion in the neonatal unit. Insertion took place mainly in premature newborns, with gestational age below 37 weeks and with very low weight, between 1,000 and 1,499 grams.

Prematurity is one of the main diagnoses for admission in neonatal units, and is considered a clinical vulnerability, due to the immaturity of organs and systems, which leads to a greater susceptibility to complications, requiring intravenous therapy for a long period and being identified as the most prevalent justification for PICC insertion ${ }^{(3,9,10)}$.

Premature newborns have peculiarities inherent to the condition of early birth, which prevent the maturation of organs and systems even intrauterinely, including the vascular system, which shows fragile venous network in this profile of patients. However, there are strategies that can mitigate the existing anatomical and physiological limitations, such as a thorough and careful inspection of the venous network by a trained professional, heating the limb of choice before the puncture to promote vasodilation and consequently increase the lumen of the vein to be catheterized, which favors its visualization and reduces the chances of errors during PICC insertion $^{(11,12)}$.

Regarding the Apgar score, the results of the present study demonstrate that most newborns, despite being premature, had Apgar above 7 in the first and fifth minutes of life, a finding similarly confirmed by a survey conducted in Rio Grande do Sul ${ }^{(13)}$.

A study carried out in 2014, with the objective of evaluating the use of PICC in a NICU, analyzed 195 records of newborns, corroborating the findings of this research, by showing that most PICC insertions occurred mainly in preterm infants $(71.8 \%)^{(3)}$.

Research carried out in Foz do Iguaçu, which analyzed the use of the PICC in the NICU, corroborates the findings of the present study in which antibiotic therapy and parenteral nutrition are the most indicated for PICC insertion. The immaturity of the immune system can lead to susceptibility to infections, requiring therapeutic support with antibiotics. Gastric immaturity often prevents the start of enteral feeding, leading to the start of parenteral nutrition during the first days of hospitalization ${ }^{(3)}$, ensuring a safe intravenous route for a prolonged period of treatment.

The study host institution is a reference hospital for high-risk pregnant women, which contributes to the predominance of premature and very low birthweight newborns. Furthermore, this clientele, due to their weight often below 1,500 grams, has an express indication for the use of intravenous nutritional therapy in the first 24 hours of life, which is a routine practiced at the institution where the study was conducted. 
They also have the characteristic of being newborns at risk for neonatal infection, due to premature labor, often with ruptured membranes and/or mother with urinary infection being treated or untreated, which leads to the indication of early use of antibiotic therapy for the prevention of early neonatal sepsis, as per institutional protocol routine.

Regarding blood vessels for PICC catheterization, this study reveals that the most prevalent were the basilic, cephalic and axillary veins. The literature shows that the most suitable veins for catheter insertion are the basilic and cephalic veins, as they have a favorable anatomy, larger caliber, fewer valves and a shorter path to the superior vena cava. However, the cephalic vein, having a smaller caliber than the basilic and having more valves, poses a potential risk for phlebitis and malpositioning ${ }^{(14)}$ and difficulty for advancement in the right hemiclavicular region ${ }^{(15)}$.

A study carried out in Foz do Iguaçu, analyzing the use of PICC in 195 forms for newborns in a neonatal unit, corroborated the finding of the present study in which the basilic vein $(44.1 \%)$ was the most catheterized during PICC insertion ${ }^{(3)}$.

Although evidence shows the advantages of using the basilic vein as a first choice, studies describe PICC insertion in other sites, namely, jugular ${ }^{(15)}$, axillary ${ }^{(16)}$, and median cubital, and saphenous ${ }^{(17)}$ veins.

The search for other insertion sites may be associated with the fragility of the venous network in these severely preterm infants, long hospital stays associated with repeated venous punctures, the need to insert more than one catheter in the same patient at different times, which requires the use of alternative blood vessels. Furthermore, as this is a retrospective study, the practice of identifying the right antecubital region with gauze and tape written "protected for PICC" to preserve the basilic and cephalic veins was not yet part of the institution's routine.

This practice began to be used in the maternity hospital, where the study was conducted, in September 2017, with the identification of the antecubital region to preserve the right upper limb when the newborn is admitted to the neonatal unit. This guidance is given by the intravenous therapy committee to all nursing professionals, and is service's routine, being part of best practice activities in the care of newborns in a neonatal unit, supervised and audited within the institution.

As for the number of puncture attempts for catheter insertion associated with the catheterized vein, it is shown that the basilic vein had a lower median in the number of puncture attempts. These data show that this is the vein of choice for PICC insertion, which is the institution's routine; this choice is motivated by the advantages of the basilic vein favoring the advancement of the catheter in the right hemiclavicular region ${ }^{(15)}$, having laminar flow, being shorter and having fewer valves.

The professionals' expertise in venipuncture at the institution studied, as well as the good theoretical/practical knowledge about the venous network, the frequent guidance given by the intravenous therapy committee to professionals, and the routine of PICC insertion adopted by the institution based on standard operating procedure and protocols favor a humanized practice aimed at patient safety.

A similar study, which assessed the practices of insertion and maintenance of PICC for three years, showed that among the 137 newborns evaluated, most were premature (87.6\%) and with very low birth weight (35\%), revealing that the nurses were successful in insertion in up to four puncture attempts $(73.7 \%)^{(18)}$.

When the newborn is exposed to multiple peripheral punctures for central catheter insertion, vessels permeability and the risk of developing infections and thrombosis increase significantly ${ }^{(6,9,11)}$.

In addition, PICC insertion is one of the most painful procedures performed in newborns, requiring the use of non-pharmacological practices for pain relief, such as facilitated containment (tucking), non-nutritive sucking, and $25 \%$ glucose, demonstrating humanization of newborn care in neonatal units ${ }^{(17,19)}$.

At the institution where the study was conducted, sucrose suction is used, at least five minutes before the procedure, to promote non-pharmacological pain relief. Some newborns benefit from the use of fentanyl citrate for pain relief, as the institution's routine is the continuous infusion of this opioid when the newborn is on mechanical ventilation.

The research also demonstrated that the final positioning of the catheter tip after its insertion is central, although there are still peripheral positions, demonstrating the need to verify the measurement and PICC insertion technique. This finding is corroborated by a study that evaluated the nursing practices related to PICC in a NICU, where $60.6 \%$ of the catheters were centrally positioned, but still with a significant number of non-central sites, requiring traction maneuvers for their repositioning ${ }^{(18)}$.

Moreover, a study carried out in a tertiary hospital in New York revealed that, among the 176 catheters included in the survey, 55\% were in a central position, $36 \%$ in an intermediate position, and $9 \%$ in a peripheral position. Babies with centrally positioned catheters had a significantly lower complication rate than those with intermediate or peripheral $\mathrm{PICC}^{(7)}$.

In contrast, a retrospective study carried out over a tenyear period, which aimed to assess the duration and rates of complications associated with PICC in relation to the different positions of the catheter in extremely preterm newborns, found that catheters inserted in the lower extremity were more prone to have the tip located centrally compared to catheters inserted in the upper extremities ${ }^{(20)}$.

This study showed the effectiveness of using PICC in specialized care for newborns admitted to the neonatal unit. With the creation of the intravenous therapy committee, there was an improvement in the quality of PICC insertions, with a standardization of the actions of the nursing team, allowing the improvement in care and safety of neonatal patients using PICC. The indicators of good practice are evidenced in the data, where most PICCs were inserted in the basilic vein, in the first and second puncture, with central positioning. 
The limitation of the study refers to the lack of complete information in the forms about the variables gestational age, birthweight and weight on the day of insertion, sex, APGAR, due to incomplete filling of the forms.

\section{CONCLUSION}

The results of this study highlight the continuing need to improve technical-scientific knowledge to qualify actions in neonatology, especially with regard to the use of PICC during long-term intravenous therapies, as well as the adequate and complete recording of data of insertion.

It is believed that this study can support future research dealing with interventions for the training of professionals during the manipulation of PICC, to ensure a safe practice that contributes to the development and incorporation of strategies to minimize risks in care and that ensure patient safety, with reduction in neonatal morbidity and mortality.

\section{RESUMO}

Objetivo: avaliar a utilização do cateter central de inserção periférica quanto ao perfil do neonato, indicações para uso e veia cateterizada; relação entre o número de tentativas de punção e veia e avaliação do posicionamento da ponta do cateter. Método: estudo documental, descritivo, retrospectivo, quantitativo, desenvolvido em maternidade terciária no Ceará. Foram incluídos 3.005 formulários de inserção de PICC e excluídos 1.583 devido a incompletude dos dados, obtendo amostra por conveniência de 1.422 inserções. Resultados: Verificaram-se 1.200 (84,4\%) neonatos com idade gestacional menor que 37 semanas; 781 (54,9\%) do sexo masculino; escore de Apgar acima de 7 no primeiro $(628-44,2 \%)$ e quinto minutos $(1.085-76,3 \%)$ e peso entre 1.000 e 1.499 gramas no dia da inserção (417-29,3\%). A antibioticoterapia apresentou 1.155-53,8\% indicações para inserção; a basílica foi a veia mais utilizada (485-34,1\%); veia basílica e cefálica apresentaram menor mediana de tentativas de punções e 1.124-79\% inserções apresentaram posicionamento central. Conclusão: Os resultados desta pesquisa ressaltam a necessidade contínua de aperfeiçoar o conhecimento técnico-científico no sentido de qualificar as ações em neonatologia.

\section{DESCRITORES}

Cateterismo Periférico; Cateterismo Venoso Central; Recém-nascido; Cuidados de Enfermagem; Unidades de Terapia Intensiva Neonatal.

\section{RESUMEN}

Objetivo: evaluar el uso de catéter central de inserción periférica en función del perfil del neonato, indicaciones de uso y vena cateterizada; relación entre el número de intentos de punción y vena y evaluación del posicionamiento de la punta del catéter. Método: estudio documental, descriptivo, retrospectivo, cuantitativo, desarrollado en una maternidad terciaria en el estado de Ceará. Se incluyeron 3.005 formularios de inserción de catéter central de inserción periférica y se excluyeron 1.583 por falta de datos, obteniendo un muestreo por conveniencia de 1.422 inserciones. Resultados: Se observaron $1.200(84,4 \%)$ recién nacidos con edad gestacional menor a 37 semanas; 781 (54,9\%) hombres; puntuación de Apgar superior a 7 en el primer (628-44,2\%) y quinto minutos (1.085-76,3\%) y peso entre 1.000 y 1.499 gramos en el día de la inserción (417-29,3\%). La terapia con antibióticos tuvo 1.155-53,8\% de indicaciones de inserción; la vena basílica fue la más utilizada (485-34,1\%); las venas basílica y cefálica tuvieron mediana más baja de intentos de punción y 1.124-79\% de las inserciones se realizaron en posicionamiento central. Conclusión: Los resultados de esta investigación destacan la necesidad continua de perfeccionar el conocimiento técnico-científico para calificar las acciones en neonatología.

\section{DESCRIPTORES}

Cateterismo Periférico; Cateterismo Venoso Central; Recién Nacido; Atención de Enfermería; Unidades de Cuidado Intensivo Neonatal.

\section{REFERENCES}

1. Sirqueira LA, Souza KF. Cuidados de enfermagem na manutenção do cateter central de inserção periférica no recém-nascido. Revista da Universidade Vale do Rio Verde. 2017;15(1):139-51. DOI: http://dx.doi.org/10.5892/ruvrd.v15i1.4021.

2. Sena EMAB, Bastos MLA, Nagliate PC, Costa LC, Lopes MMCO, Lúcio IML. Peripheral venipucture in prematuros: nursing care for patient safety. Journal of nursing UFPE on line. 2018;12(1):1-10. DOI: https://doi.org/10.5205/1981-8963-v12i1a25229p1-10-2018.

3. Silva RMM, Lui AM, Ferreira H, Franca AFO, Lala ERP, Viera CS. Analysing the use of peripherally inserted central cateter in neonatology. Journal of nursing UFPE on line [Internet]. 2016 [cited 2019 Jul 20];10(2):796-804. Available from: https://periodicos.ufpe.br/revistas/ revistaenfermagem/article/view/11022.

4. Santo MKD, Takemoto D, Nascimento RG, Nascimento AM, Siqueira E, Duarte CT, et al. Peripherally inserted central venous catheters: alternative or first choice vascular access? J Vasc Bras. 2017;16(2):104-12. DOI: https://dx.doi.org/10.1590/1677-5449.011516.

5. Conselho Federal de Enfermagem. Resolução COFEN 258, de 12 de julho de 2001. Inserção de cateter periférico central pelos enfermeiros [Internet]. Rio de Janeiro; 2001 [cited 2019 Apr 06]. Available from: http://www.cofen.gov.br/resoluo-cofen-2582001_4296.html.

6. Gorski L, Hadaway L, Hagle ME, Mcgoldrick M, Orr M, Doellman D. Infusion Therapy Standards of Practice. J Inf Nurs [Internet]. 2016 [cited 2019 Jul 08];39(1S):S1-S159. Available from: https://portaldeboaspraticas.iff.fiocruz.br/biblioteca/infusion-therapy-standards-ofpractice/.

7. Goldwasser B, Baia C, Kim M, Taragin BH, Angert RM. Non-central peripherally inserted central catheters in neonatal intensive care: complication rates and longevity of catheters relative to tip position. Pediatr Radiol. 2017;47:1676-81. DOI: https://dx.doi.org/10.1007/ s00247-017-3939-1.

8. Júnior CAA, organizador. Relatório de Produção Assistencial 2018 [Internet]. Fortaleza: Museu Escola Assis Chateaubriand, Gerência de Atenção à Saúde; 2018 [cited 2021 Apr 22]. Available from: http://www2.ebserh.gov.br/web/meac-ufc/relatorio-de-gestao1.

9. Cheng HY, Lu CY, Huang LM, Lee PI, Chen JM, Chang LY. Increased frequency of peripheral venipunctures raises the risk of centralline associated bloodstream infection in neonates with peripherally inserted central venous catheters. J Microbiol Immunol Infect. 2016;49(2):230-6. DOI: https://dx.doi.org/10.1016/j.jmii.2014.06.001. 
10. Wen J, Yu Q, Chen H, Chen N, Huang S, Cai W. Peripherally inserted central venous cateter-associated complications exert negative effects on body weight gain in neonatal intensive care units. Asia Pac J Clin Nutr. 2017;26(1):1-5. DOI: https://dx.doi.org/10.6133/ apjen.112015.07.

11. Li R, Cao X, Shi T, Xiong L. Application of peripherally inserted central catheters in critically ill newborns experience from a neonatal intensive care unit. Medicine. 2019;98(32):e15837. DOI: http://dx.doi.org/10.1097/MD.0000000000015837.

12. Leite AC, Silva LA, Silva MPB, Silva ML, Alves RSS, Gomes BP, et al. Nurses' performance in handling peripheral insertion central venous catheters in Neonatal Intensive Care Units. Research, Society and Development. 2021;10(2):e59010212974. DOI: http://dx.doi. org/10.33448/rsd-v10i2.12974.

13. Damian A, Waterkemper R, Paludo CA. Profile of neonates hospitalized at a neonatal intensive care unit: a cross-sectional study. Arquivos de ciências da saúde. 2016;23(2):100-5. DOI: https://dx.doi.org/10.17696/2318-3691.23.2.2016.308.

14. Martins C, Oselame GB, Neves EB. Cateter Central de Inserção Periférica: revisão sistemática. Peripherally inserted central catheter: systematic review. Revista de Atenção à Saúde. 2016;14(47):99-107. DOI: https://dx.doi.org/10.13037/ras.vol14n47.3358.

15. Nobre KSS, Cardoso MVLML, Teixeira JL, Lopes MMCO, Fontenele FC. Use of peripherally inserted central catheter in a neonatal unit: a descriptive study. Online Brazilian journal of nursing. 2016;15(2):215-25. DOI: https://doi.org/10.17665/1676-4285.20165420.

16. Costa P, Kimura AF, Brandon DH, Damiani LP. Predictors of Nonelective Removal of Peripherally Inserted Central Catheters in Infants. Biological Research for Nursing. 2016;18(2):173-80. DOI: http://dx.doi.org/10.1177/1099800415590856.

17. Borghesan NBA, Demitto MO, Fonseca LMM, Fernandes CAM, Costenaro RGS, Higarashi IH. Peripherally inserted central catheter: practics of nursing team in the neonatal intensive care. Revista enfermagem UERJ. 2017;25:e28143. DOI: http://dx.doi.org/10.12957/ reuerj.2017.28143.

18. Rangel RJM, Castro DS, Amorim MHC, Zandonade E, Christoffel MM, Primo CC. Practice of Insertion, Maintenance and Removal of Peripheral Inserted Central Catheter in Neonates. Revista de pesquisa, cuidado é fundamental online [Internet]. 2019 [cited 2020 May 08];11(n. esp):278-84. Available from: http://seer.unirio.br/index.php/cuidadofundamental/article/view/6425/pdf.

19. Kegler JJ, Paula CC, Neves ET, Jantsch LB. Pain management in the use of the peripherally inserted central cateter in newborns. Escola Anna Nery [Internet]. 2016 [cited 2019 Jan 22];20(4):e20160099. Available from: https://www.scielo.br/j/ean/a/PZwBFH8LcMBNQ6v yCfgKxTf/?lang=en.

20. Van Den Berg J, Lööf JA, Olofsson J, Fridlund M, Farooqi A. Peripherally inserted central catheter in extremely preterm infants: Characteristics and influencing factors. J Neonatal Perinatal Med. 2017;10(1):63-70. DOI: https://dx.doi.org/10.3233/NPM-16105. 